\title{
Hydromorphological characteristics of the rivers of Algeria
}

\author{
Nureddin Maalem*, and Ilkhom Begmatov \\ Tashkent Institute of Irrigation and Agricultural Mechanization Engineers, Tashkent, \\ Uzbekistan
}

\begin{abstract}
The article presents the results of a study on the water regime of the rivers of Algeria, which are characterized by a flood feeding regime. The flood regime is mainly formed from heavy rains, the flow of which is $80-90 \%$ of the annual flow. Due to the short duration of rain floods, stationary hydrological posts do not always register them, so they can be characterized as single-modal, which simplifies their design possibilities. For the design of hydrographs of rain floods, a parabolic model-a flood scheme is adopted, and the main characteristics of hydrographs are determined according to this scheme.
\end{abstract}

\section{Introduction}

Agriculture is a branch of the economy to provide the population with work, food, and obtaining raw materials for several industries. In addition, agriculture ensures the food security of each state. The development of agriculture is associated with the development of new lands, their guaranteed water supply, and the construction of large water management complexes.

The reliability and durability of water management structures, first of all, requires proper consideration in the projects of the hydrological regime of rivers and the hydromorphological characteristics of their channels [1-6]. Every year, during floods and heavy rains, the banks of riverbeds, bridge crossings, hydraulic structures are eroded, acreage is flooded, and the basins of reservoirs are silted up, etc. In addition, in many countries of the world, due to the rain supply of rivers, there is a dry period to waterlessness in the summer. At the same time, many crops are lost. Restoration of working capacity and ensuring their reliable operation should be based on scientifically based data on the hydrology and hydromorphology of rivers [7-14].

The water regime of the rivers of Algeria is described below. Meal Algerian rivers Badoiu, Beselam, Jedi, Medjerda, Mina, Isser, Masatran, Sabus, Tufina, Sheriff, and others are rain, developing in warm climates [1]. Due to the weak knowledge of the hydrology of rivers and the practical lack of knowledge of the hydromorphology of their channels, the above-mentioned technogenic processes occur in the country [25-29].

Factors affecting the river regime are precipitation, evaporation, filtration, wind, air temperature, terrain, soil, etc. The regime of rivers is also affected by water management

*Corresponding author: yuviper29@gmail.com 
measures: regulation of riverbeds and water flow by dams, flood protection measures, and water transfer from other basins.

A flood feeding regime characterizes the rivers of Algeria. From October to May, there is an average of 90 to $100 \%$ of the annual runoff and very low inter-water costs in the rest of the year. The differences between the flow rates are measured in hundreds and thousands of $\mathrm{m} 3 / \mathrm{s}$, and in the low water, it drops to negligible values [7]. The amount of summer precipitation is insignificant, and the water regime is determined by precipitation. However, in the Sahara Hydrographic region, precipitation is confined to the summer period. Since the amount of precipitation is insignificant in summer, transpiration absorbs most of the runoff of low-water rivers in Algeria [7-9].

The water resources of the Northern waterways al-Jazira equal $12.57 \mathrm{~km} 3$, which are formed directly in the specified territory with an area of $193910 \mathrm{~km}$ (Tab. 1). According to estimates, in the basins of rivers flowing into the Mediterranean sea, [7] formed by 11.9 $\mathrm{km}^{3}$ of water, that is almost $95 \%$ of the total runoff of the Northern al-Jazira, and within the inner closed basins, only $0.67 \mathrm{~km}^{3}$, or $5 \%$. According to the statistical yearbook of Algeria $[1,2]$, in the west of the territory, an average of $2.21 \mathrm{~km} 3$ of water is formed, or $18 \%$ of the flow of all the watercourses of the Northern Al-Jazayr, and in the east $10.36 \mathrm{~km} 3$ or $82 \%$.

Such a significant difference in the water content of remote areas of Northern Algeria is due to the conditions of runoff formation in each of the regions and, above all, the amount and distribution of precipitation, as well as the formation of runoff layers, which are equal to 83.0 and $7.0 \mathrm{~mm}$, respectively, with runoff coefficients of 0.15 in the northern and 0.024 in the southern regions. According to the map of Africa's average annual flow layer, about $2.7 \mathrm{~km} 3$ of water is formed within the Algerian Sahara. This means that the average annual runoff layer in the Sahara barely exceeds $1.0 \mathrm{~mm}$. Thus, the surface water resources of the territory of Algeria, taking into account the flow of the Sahrawi hydrographic region within the state borders, are equal to $15.27 \mathrm{~km}^{3}[2,7]$.

Table 1. Average annual flow of Northern Algeria regions

\begin{tabular}{|c|c|c|c|c|}
\hline $\begin{array}{c}\text { Districts of Northern } \\
\text { Algeria }\end{array}$ & $\begin{array}{c}\text { Catchment area, } \\
\mathrm{km}^{2}\end{array}$ & \multirow{2}{*}{$\begin{array}{c}\text { Average annual } \\
\text { flow, } \mathrm{m}^{3}\end{array}$} & \multicolumn{2}{|c|}{ Average annual balance } \\
\cline { 4 - 5 } & & & $\mathrm{mm}$ & $\begin{array}{c}\% \text { of } \\
\text { average }\end{array}$ \\
\hline El Jazair & 27690 & 600 & 22 & 34 \\
\hline Shelf and coast of Dahra & 48600 & 1720 & 35 & 54 \\
\hline Al Jazeera (the center) & 8720 & 1500 & 172 & 276 \\
\hline Sebau and coastal ueda & 3900 & 1600 & 410 & 681 \\
\hline Summam & 9200 & 750 & 82 & 126 \\
\hline Ores-Honda & 61000 & 900 & 15 & 23 \\
\hline El Jazair-Eastern & 34800 & 5500 & 158 & 243 \\
\hline North Al Jazair & 193910 & 12570 & 65 & 100 \\
\hline
\end{tabular}

\section{Methods}

The study of the rivers of Algeria is described below. The hydrology of the territory of the People's Democratic Republic of Algeria is poorly studied. The study of the hydrology of the territory of Algeria was mainly limited to the consideration of the regularities of precipitation distribution. For the first time, based on the analysis of measurement data before 1968, it was established $[7,8]$ that the annual flow rate, in addition to the sediment rate, also depends on the average height of the catchment, that is,

$$
M_{0}=f\left(H_{c p}, P_{o}\right)
$$


With precipitation in the basin from 200 to $900 \mathrm{~mm}$, this dependence has the following analytical form

$$
M_{0}=K_{v}\left(0.0019 P_{0}\right)^{3.57}
$$

- and with precipitation in the basin from 900 to $1800 \mathrm{~mm}$

$$
M_{0}=K_{v}\left(0.0236 P_{0}-14.2\right)
$$

Where: $M_{0}$ is flow rate, $1 / \mathrm{s} \mathrm{km}$;

$P_{0}$ is sediment rate, $\mathrm{mm}$;

$K_{v}$ is the coefficient that characterizes the degree of influence of the average height of the catchment area on the runoff, with the same amount of precipitation.

The $K_{v}$ values depending on the average height of the catchment area are determined from Table 2.

Table 1. $K_{v}$ values depending on the average height of the catchment area

\begin{tabular}{|c|c|c|c|c|c|c|c|c|c|c|}
\hline$H_{a v}, \mathrm{~mm}$ & 0 & 200 & 400 & 600 & 800 & 1000 & 1200 & 1400 & 1600 & 1800 \\
\hline$K_{v}$ & 1.0 & 1.06 & 1.12 & 1.18 & 1.24 & 1.32 & 1.40 & 1.49 & 1.59 & 1.70 \\
\hline
\end{tabular}

The calculation data [7] showed that in the west of the territory of Northern Algeria, an average of $2.21 \mathrm{~km}^{3}$ of water or $18 \%$ of the total flow is formed, and in the east $10.36 \mathrm{~km}^{3}$ or $82 \%$. The calculation also found that only $2.7 \mathrm{~km}^{3}$ of water is formed within the Algerian Sahara. This means that the average sediment layer in this region of Algeria does not exceed $1 \mathrm{~mm}$.

Thus, as shown in Table 2 and the estimated data provided, Algeria's water resources are very diverse. This is due to the diversity of the distribution of the sediment norm.

Study of the hydrological characteristics of rivers. The construction of any hydraulic or other engineering structures in the riverbed affects its natural regime. At the same time, the depth and width of the cross-section, the flow velocity change, the level difference are formed, the water flow is redistributed, and the bottom and suspended sediments.

When constructing an engineering structure, it is necessary to correctly anticipate its effects on the river, ensure the reliability of the structure itself, guarantee its quality operation, and take into account side effects. First of all, this requires studying and anticipating the hydrological regime of the river, in which conditions water management complexes will operate [3-6].

Forecast data on the river regime are the basis for determining the types and sizes of reservoirs, dams, bridges, and other structures of water management systems.

Forecasting should cover the entire period during which it is expected to guarantee the performance of the assigned function of the water management system.

The feeding regime of the rivers of Algeria. The main source of nutrition of the rivers of Algeria is heavy rains [7]. Their flow is $80-90 \%$, so the rivers of Algeria have a rain supply (Figure 1, 2, and 3). 


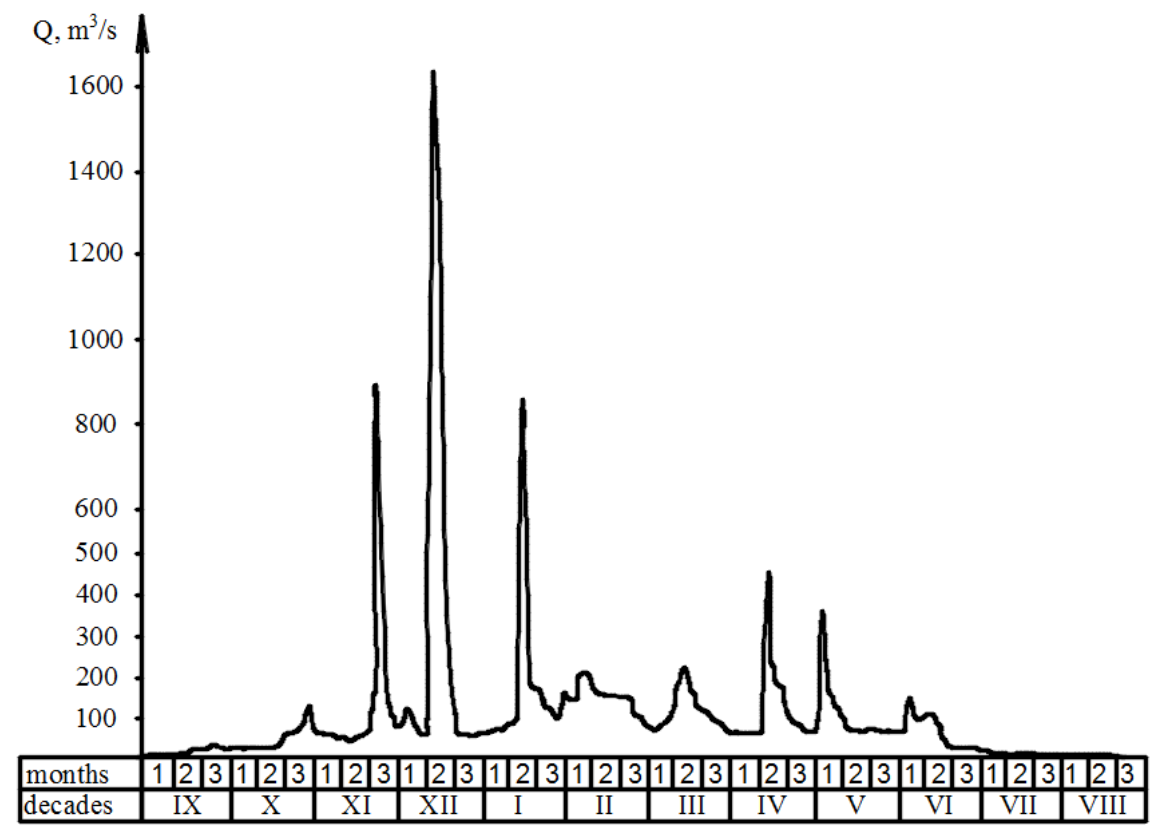

Fig. 1. Hydrograph of the water flow of the Shelef river observed in 1959-1960y. at the sash of Sidi Bel Atar $Q_{\max }=1106.6 \mathrm{~m}^{3} / \mathrm{s}$

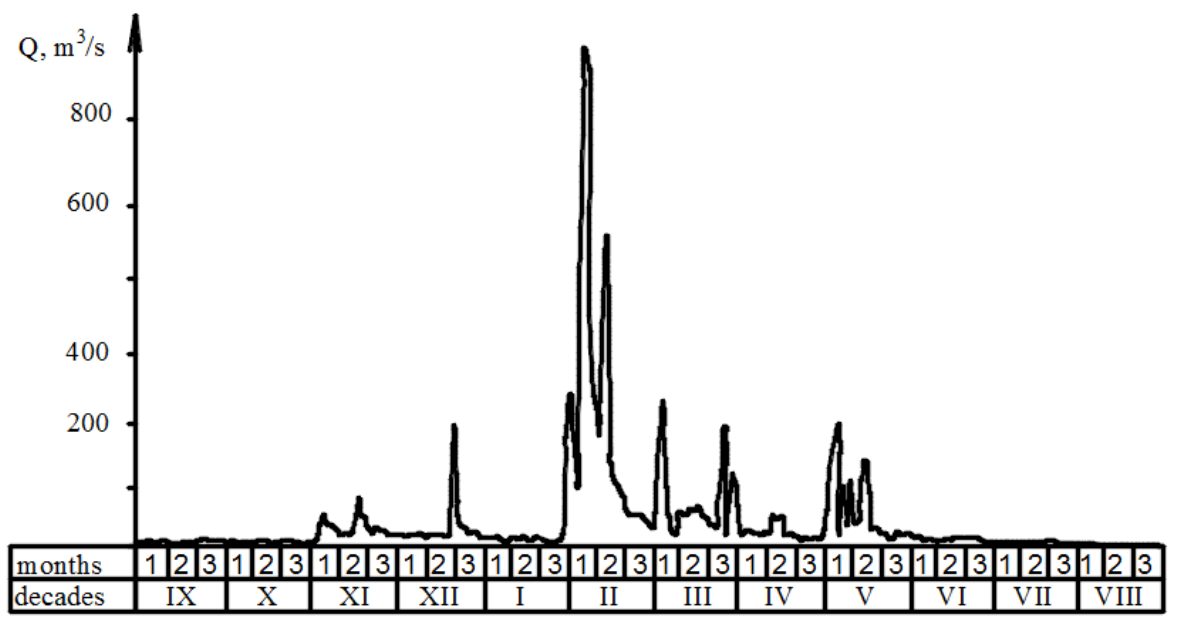

Fig. 2. Hydrograph of the water flow of the Shelef river observed in 1975-1976y at the sash of Sidi Bel Atar $Q_{\max }=38.679 \mathrm{~m}^{3} / \mathrm{s}$

One of the most important phases of the hydrological regime is rain floods. The rain flood is characterized by the leash flow, the period of rise and fall, the total duration of the flood, the amplitude of the flood flow, as well as the number of floods per year. Therefore, it is advisable to study only the part of hydrographs that is formed due to rain floods 


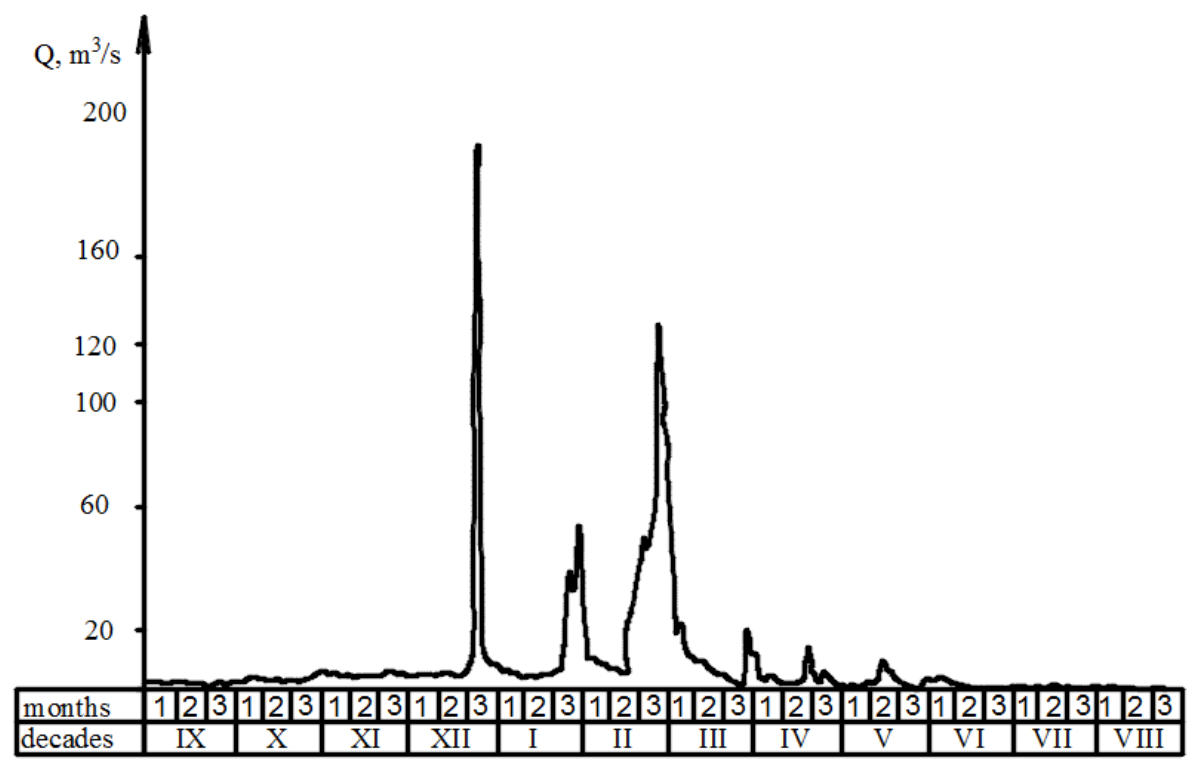

Fig. 3. Hydrograph of the water flow rate of the Shelef River observed in 1981-1982 at the Sidi Bel Atar alignment $Q_{\max }=0.059 \mathrm{~m}^{3} / \mathrm{s}$

\section{Results and Discussion}

A characteristic feature of these floods is their short duration (up to 1 day). Therefore, stationary hydrological measurements do not always record the passage of maxima between the observation periods. Basically, flood hydrographs in the considered territory can be characterized as single-modal, which simplifies the possibilities of their design $[9,10]$.

There are methods for designing hydrographs of rain floods by D. I. Kocherin, G. A. Alekseev, Semagref (France) [11] and the method of Lajel Mahmud, E. D. Hopchenko, V. A. Ovcharuk [9]. The latter authors studied the hydrographs of rain floods in the rivers of Algeria.

For the design of hydrographs of rain floods, a parabolic model-the flood scheme is adopted. According to this scheme, it is necessary to determine the main characteristics of hydrographs: the duration of the rise $\left(t_{n}\right)$, the estimated maximum flow rate $\left(Q_{\max }\right)$, and the duration of the decline $\left(t_{c n}\right)$.

The duration of a flood $T_{n}$ consists of two components: the rise time $\left(t_{n}\right)$ and the fall time $\left(t_{c n}\right)$. These values can be related to each other by the relation $-t_{c n}=\gamma t_{n}$. If we express the duration of the flood- $T_{n}$ as a function of the time of rise- $t_{n}$, that is

$$
T_{n}=(\gamma+1) t_{n}
$$

The parameter- $\gamma$, it is recommended to normalize depending on the catchment area-F. Thus, the equation of the form is justified-

$$
\left.\gamma=0.03(F+1)^{0.65}+1.0\right]
$$

Determining the time of the flood is described below. The channel flow is the result of the transformation of the slope tributary by the channel system. Consider the case when the 
channel length is seeking more of the length of slope inflow; this is, $t_{p}>T_{0}$, the maximum discharge is formed due to the entire layer of slope flow, but only part of the catchment. As a result of river-floodplain regulation, the maximum flow rate occurs after the end of the slope inflow. Thus, the time of ascent- $t_{\Pi}$ will be less than the time of the channel reach but greater than or equal to the duration of the slope inflow- $\mathrm{T}_{0}$.

The dependence [9] between the relative rise time $\left(t_{n} / T_{0}\right)$ and the relative duration of the riverbed reach time $\left(t_{p} / T_{0}\right)$, which is analytically described by the equation, is established on the materials of the observed high floods (Figure 4).

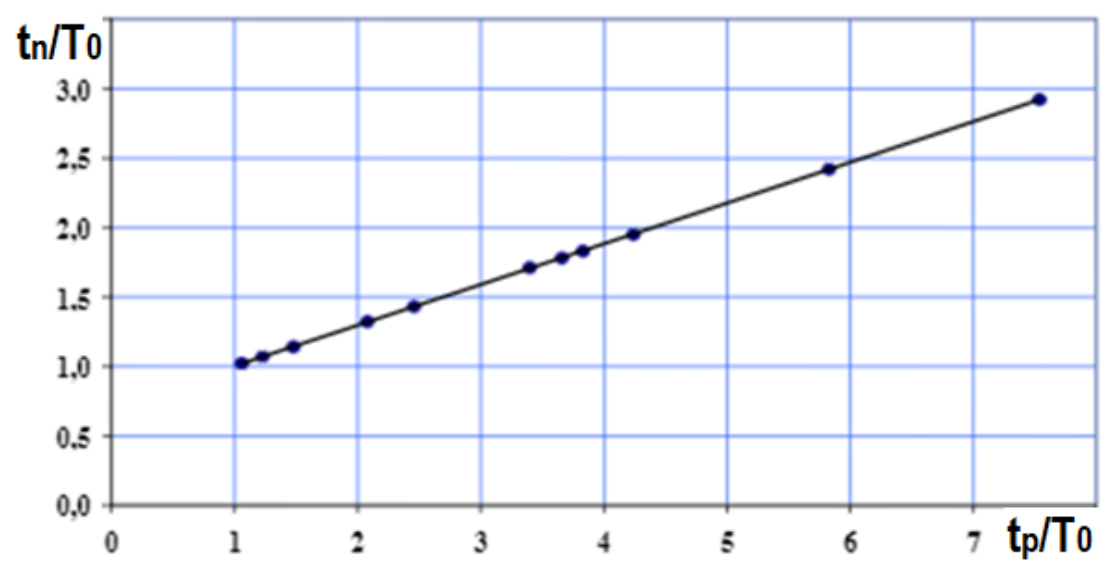

Fig. 4. Dependency $\left(t_{n} / T_{0}\right)=\mathrm{f}\left(t_{p} / T_{0}\right)$

The inflow duration is $T_{0}$, is subject to geographical zoning, and is represented in the form of maps [12], and the maximum values are- $T_{0}$, close to five o'clock.

The design of rain flood hydrographs in the form of parabolic triangles requires determining the degree indicators of both their branches- $m$ and $n$. As a result of numerical experiments for exponents of degree- $m$, the following equation is obtained for the condition $t_{p}>T_{0}[9]$.

$$
m=1 / n_{2}+1
$$

Where: $n_{2}$ is the exponent in the slope inflow equation.

The exponent- $n$, in the equation of the decline curve, is determined by the following formula of D.L. Sokolovsky [13].

$$
n=\frac{k \gamma(m+1)}{(m+1)(\gamma+1)-k}-1
$$

Where: $k=m_{1}+1 / m_{l--}$ is coefficient of unevenness of the flood flow $m_{1}$ is the exponent in the equation of the channel flow hydrograph [14]. 


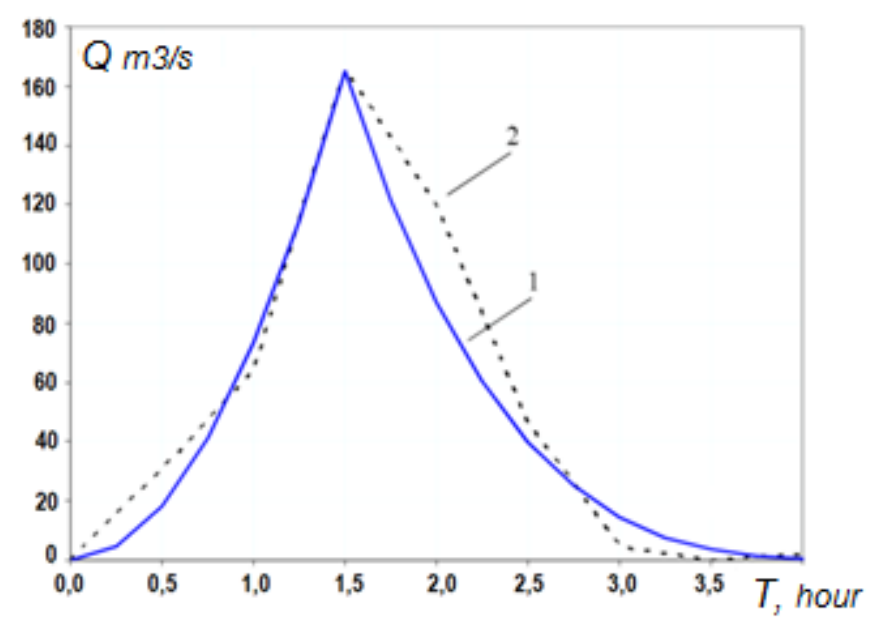

Fig. 5. Flood of 27.09.1969 on Ueda Rebua Rebia:

The exponent of the form- $m_{l}$ depends on the catchment area and is determined by the following formula

$$
m_{1}=n_{1}(F+1) \xi
$$

Where: $n \leq 0.5$ is determined experimentally; $\xi=-0.20$ for the Ueda of northern Algeria

The projected hydrographs are shown in pictures 5 and 6 .

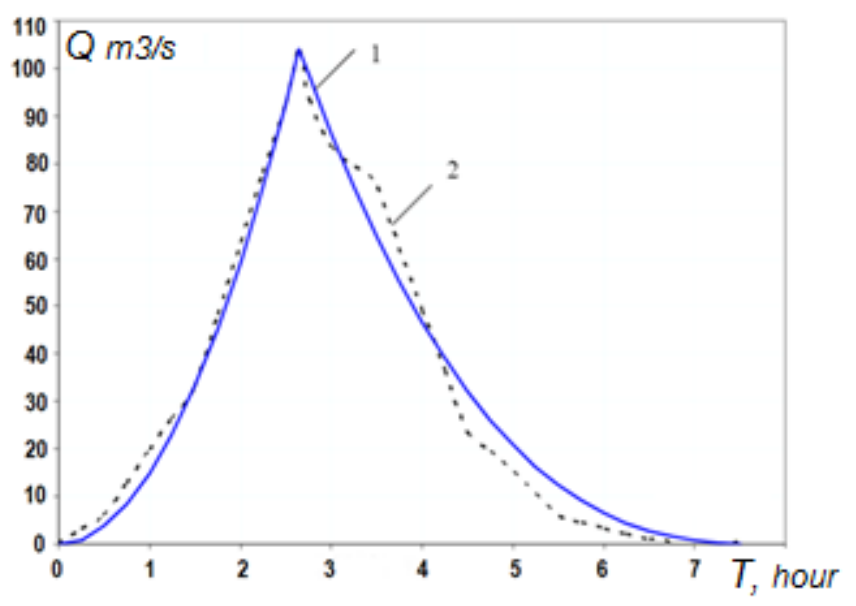

Fig. 5. Flood of 07.12.1987 on Ueda Subella-Sidi Uadah: 1 is the projected model of the authors [9, 10]; 2 is the actual hydrograph

\section{Conclusions}

1. The development of agriculture in Algeria is associated with a guaranteed water supply, which is formed mainly by heavy rainfall. 
2. Due to the weak knowledge of the hydrology of rivers and the practical lack of knowledge of the hydromorphology [3-6] of their channels, the banks of riverbeds, bridge crossings, hydraulic structures are eroded, acreage is flooded, and the basins of reservoirs are silted up, etc.

3. Such a significant difference in the water content of remote areas of Northern Algeria is due to the conditions of runoff formation in each of the areas and, above all, the amount and distribution of precipitation and the formation of runoff layers.

4. Algeria's water resources are thus very diverse. This is due to the diversity of the distribution of the sediment norm.

5. One of the most important phases of the hydrological regime is rain floods. The rain flood is characterized by the leash flow, the period of rise and fall, the total duration of the flood, the amplitude of the flood flow, and the number of floods per year.

6. A characteristic feature of these floods is their short duration (up to 1 day). Therefore, stationary hydrological measurements do not always record the passage of maxima between the observation periods.

7. Hydrographs of rain floods in the territory under consideration can be characterized as single-modal, which simplifies their design possibilities.

8. For the design of hydrographs of rain floods, a parabolic model-a flood scheme is adopted. According to this scheme, it is necessary to determine the main characteristics of hydrographs.

9. Comparing the calculated hydrographs designed according to the authors ' method $[9,10]$ with the observed ones showed that the proposed method generally provides a satisfactory result.

\section{References}

1. Statistical Yearbook of Algeria. - p.18, - Algeria, (1961)

2. Padun N. N. Annual runoff and water balance of Northern Algeria. Abstract of the dissertation of the Candidate of Geographical Sciences. - 21 p. Moscow, (1974)

3. Antropovsky V. I., Denisova I. V., Izotov A. B. Hydrological and morphological direction of research of channel processes. Izvestiya RGPU im. And Herzen: Natural and exact Sciences. St. Petersburg, no. 5 (13), pp.233-241. (2005)

4. Antropovsky V. I. Hydrological and morphological regularities and background forecasts of riverbed re-formation. - St. Petersburg: Christmas+, - p.216, (2006)

5. Khasanov, K. Evaluation of ASTER DEM and SRTM DEM data for determining the area and volume of the water reservoir. IOP Conference Series: Materials Science and Engineering, (2020), 883(1), 012063

6. Rakhmatullaev, S., Huneau, F., Celle-Jeanton, H., ...Motelica-Heino, M., Bakiev, M. Water reservoirs, irrigation and sedimentation in Central Asia: A first-cut assessment for Uzbekistan. Environmental Earth Sciences, 68(4), pp.985-998, (2013)

7. Shelukhina O. A. The current state and forecast of the channel regime and hydromorphological characteristics of the left-bank tributaries of the Middle Volga. (2008)

8. Kiselev D. V., Zemtsov V. A. Hydromorphological dependencies for the rivers of the Tomsk region. Journal of Earth Sciences, - pp.169-173, (2011)

9. Maalem Noureddine Hydromorphological characteristics of the rivers of Algeria and recommendations for their calculation. Dissertation for the degree of Candidate of Technical Sciences, - p.171, Tashkent, (1993)

10. Khasanov Kh, M Bakiev, J Choriev, A Jakhonov, A Khalimbetov. Water Reservoir Area and Volume Determination Using Geoinformation Technologies and Remote 
Sensing. International Journal of Recent Technology and Engineering 4 (8), pp.54585461.

11. Rivers of Algeria. ru.wikipedia.org $>$ wiki $>$ requir_alzhira.

12. Lodzhel M., Gopchenko E. D., Ovcharuk V. A. Design of hydrographs of rain floods on the oued of Algeria. docplayer.ru"144119102... gidrografov...na....alzhira.html, Ukrainian Hydrometeorological Journal, No. 5, - from pp.199-204, (2009)

13. Ladjel M. A propos de l'application de la formule de calcul du debit maximum des crues pluviales. Sevinaire National d'Hydraulique, SNHYCO8, Chief, Algerie, (2008)

14. Bakiev, M.R., Kirillova, E.I., Hujaqulov, R. Safety of hydraulic structures. p.110, Tashkent, (2008)

15. Petits Barrages «Recommandations pour la conception, la realization et le suivi». Cemagref, p.34, (2002)

16. Local M., Gopchenko E. D., Ovcharuk V. A. calculate the duration of inflow of water from the slopes during rainfall floods in Ueda North of Algeria.Meteorologiya, klimatologiya and gidrologiya, Odesa, Ekologiya, issue 50, part 2, - pp.84-92, (2008)

17. Sokolovsky D. L. River flow. Hydrometeoizdat, Leningrad, 1968. 540 p.

18. Hopchenko E. D., Ovcharuk V. A. Formation of the maximum flow of spring flood in the conditions of the South of Ukraine. TES, Odessa, - p.110, (2002)

19. N Maalem, Kh Khasanov and Kh Nishanbaev. Morphometric elements of the channel and hydraulic flow parameters in the zone of the river backwater. (2020) IOP Conf. Ser.: Mater. Sci. Eng. 883012013.

20. Nureddin Maalem1, Ilkhom Begmatov1, Khojiakbar Khasanov1, Uktam Kahharov1 and Sanat Khidirov. Dynamics of hydraulic resistance in the zone of constraint of the riverbed. (2020) IOP Conf. Ser.: Mater. Sci. Eng. 869042012.

21. Yangiev, A.A., Bakiev, M.R., Muratov, O.A., Choriev, J.M., Djabbarova, S. Service life of hydraulic structure reinforced concrete elements according to protective layer carbonization criteria Journal of Physics: Conference Series 1425(1).

22. Bazarov D., Vatin N., Obidov B., and Vokhidov O. Hydrodynamic effects of the flow on the slab of the stand in the presence of cavitation. IOP Conf. Ser. Mater. Sci. Eng. 1030, 012110 (2021).

23. Bazarov D., Markova I., Norkulov B. and Vokhidov O. Hydraulic aspects of the layout of head structures during water intake from lowland rivers. IOP Conf. Ser. Mater. Sci. Eng. 1015, 012041 (2021).

24. Bazarov D., Markova I., Sultanov S. and Kattakulov F. Dynamics of the hydraulic and alluvial regime of the lower reaches of the Amudarya after the commissioning of the Takhiatash and Tuyamuyun hydrosystems. IOP Conf. Ser. Mater. Sci. Eng. 1030, 012110 (2021).

25. Bazarov D. and Vokhidov O. Extinguishing Excess Flow Energy in Spillway Structures. In book: Proceedings of EECE 2020, LNCE 150, pp. 535-545, (2021) DOI: 10.1007/978-3-030-72404-7_52

26. Obidov B., Vokhidov O., Tadjieva D., Kurbanova, U., Isakov A. Hydrodynamic effects on the flow elements of the downstream devices in the presence of cavitation. IOP Conf. Ser. Mater. Sci. Eng. 1030, 012114 (2021).

27. Bazarov D., Norkulov B., Vokhidov O., Uljaev F., Ishankulov, Z. Two-dimensional flow movement in the area of protective regulatory structures. IOP Conf. Ser. Mater. Sci. Eng. 890, 012162 (2020)

28. Matyakubov B., Begmatov I., Raimova I. and Teplova G. Factors for the efficient use of water distribution facilities. IOP Conf. Ser. Mater. Sci. Eng. 883, 012025 (2020).

29. Uralov B., Rakhmatov N., Khidirov S., Uljaev F., Raimova I. Hydraulic modes of damless water intake. IOP Conf. Ser. Mater. Sci. Eng. 1030(1), 012123 (2021) 